\title{
PERANCANGAN E-VOTING UNTUK PEMILIHAN BEM BERBASIS WEB
}

\author{
Minda Mora Purba \\ karo_727@yahoo.com
}

\begin{abstract}
ABSTRAK
Pada lembaga perguruan tinggi yang didalamnya terdapat banyak mahasiswa maka dibentuk Badan Eksekutif Mahasiswa (BEM) dan Unit Kegiatan Mahasiswa (UKM) sebagai wadah organisasi untuk membina dan mengarahkan mahasiswa. BEM universitas yang merupakan organisasi tertinggi mahasiswa tingkat universitas dengan anggota didalamnnya terdapat perwakilan dari seluruh fakultas dan UKM serta program studi atau jurusan di lingkungan universitas. Periode kepemimpinan di BEM universitas adalah satu tahun. Disetiap tahunnya akan ada pergantian Presiden BEM universitas. Selama ini proses pergantian Presiden BEM universitas dilakukan dengan cara pemilihan langsung yang diikuti oleh seluruh mahasiswa aktif. Voting telah menjadi salah satu metode untuk mengambil keputusan penting dalam kehidupan manusia. Voting digunakan untuk menghimpun aspirasi dari seluruh elemen masyarakat, dan kemudian menemukan jalan keluar yang dianggap paling baik untuk menyelesaikan permasalahan. Perkembangan teknologi informasi saat ini telah membawa perubahan yang besar bagi manusia, termasuk untuk melaksanakan voting. Penggunaan teknologi komputer pada pelaksanaan voting ini dikenal dengan istilah electronic voting atau lazim disebut e-voting. Penjelasan dalam tulisan ini dibatasi pada sistem e-voting dengan mengggunakan bahasa pemrograman PHP dan menggunakan database MySQL.
\end{abstract}

Kata kunci : e-voting, php mysql

$$
\begin{aligned}
& \text { ABSTRACT } \\
& \text { In higher education institutions where there are many students, a Student Executive } \\
& \text { Body (BEM) and Student Activity Unit (UKM) is formed as an organization to foster } \\
& \text { and direct students. University BEM which is the highest university level student } \\
& \text { organization with members in it there are representatives from all faculties and SMEs } \\
& \text { as well as study programs or departments in the university environment. The leadership } \\
& \text { period at the university BEM is one year. Every year there will be a change in the BEM } \\
& \text { of the university. During this time the process of changing the President's BEM of the } \\
& \text { university was done by direct election followed by all active students. Voting has } \\
& \text { become a method for making important decisions in human life. Voting is used to collect } \\
& \text { aspirations from all elements of the community, and then find a solution that is } \\
& \text { considered the best for solving problems. The development of information technology } \\
& \text { today has brought great changes to humans, including to carry out voting. The use of } \\
& \text { computer technology in the implementation of voting is known as electronic voting or } \\
& \text { commonly called e-voting. The explanation in this paper is limited to the e-voting } \\
& \text { system using the PHP programming language and using a MySQL database. }
\end{aligned}
$$

Keywords: e-voting, php, mysql 


\section{PENDAHULUAN}

Voting telah menjadi salah satu metode untuk mengambil keputusan penting dalam kehidupan manusia. Voting digunakan mulai dari tingkat masyarakat terkecil, yaitu keluarga, kampus, sampai dengan sebuah negara. Voting digunakan untuk menghimpun aspirasi dari seluruh elemen masyarakat, dan kemudian menemukan jalan keluar yang dianggap paling baik untuk menyelesaikan permasalahan. Dalam sebuah negara yang menganut sistem politik demokrasi, voting digunakan untuk mengambil keputusan negara yang sangat krusial, antara lain untuk memilih wakil-wakil rakyat atau untuk memilih pemimpin negara yang baru. Oleh karena itu voting membutuhkan prosedur pelaksanaan yang dapat menjamin kerahasiaan dan keabsahan dari hasil pelaksanaan voting tersebut.

Perkembangan teknologi informasi saat ini telah membawa perubahan yang besar bagi manusia, termasuk untuk melaksanakan voting. Penggunaan teknologi komputer pada pelaksanaan voting ini dikenal dengan istilah electronik voting atau lazim disebut $e$-voting. Pengertian $e$-voting secara umum adalah penggunaan teknologi komputer pada pelaksanaan voting. Pilihan teknologi komputer yang digunakan dalam implementasi dari $e$ voting sangat bervariasi, seperti penggunaan smart card untuk otentikasi pemilih, penggunaan internet sebagai sistem pemungutan suara, penggunaan touch screen sebagai pengganti kertas suara, dan masih banyak lagi pilihan teknologi yang digunakan.

Sebagai lembaga perguruan tinggi yang didalamnya terdapat banyak mahasiswa maka Bidang Kemahasiswaan $\begin{array}{llr}\text { Universitas } & \text { Dirgantara } & \text { Marsekal } \\ \text { Suryadarma } & \text { (UNSURYA) } & \text { selaku }\end{array}$ penanggung jawab terhadap kegiatan mahasiswa berkewajiban untuk membina dan mengarahkan organisasi mahasiswa yang terdiri dari Badan Eksekutif Mahasiswa (BEM) dan Unit Kegiatan Mahasiwa (UKM). BEM universitas yang merupakan organisasi tertinggi mahasiswa tingkat universitas dengan anggota didalamnnya terdapat perwakilan dari seluruh Fakultas dan UKM serta program studi atau jurusan di lingkungan universitas. Masa periode kepemimpinan BEM universitas adalah satu tahun. Disetiap tahunnya akan ada pergantian Presiden BEM universitas. Selama ini proses pergantian Presiden BEM universitas dilakukan dengan cara pemilu raya yaitu pemilihan langsung yang diikuti oleh seluruh mahasiswa aktif. Berdasarkan hal tersebut diatas maka bidang kemahasiswaan telah memutuskan untuk proses pemilu raya BEM akan dilaksanakan menggunakan e-voting. Untuk menjalankan proses tersebut maka perlu dirancang sebuah sistem yang dapat digunakan untuk pemilihan Presiden BEM universitas sehingga proses pemilihan dapat dilaksanakan secara efektif, efisien, cepat dan transparan.

\section{LANDASAN TEORI}

2.1. Definisi e-voting

1. $\quad$ E - Voting (electronic voting) adalah suatu metode pemungutan suara dan

penghitungan suara dalam suatu pemilihan dengan menggunakan perangkat elektronik. Tujuan dari electronic voting adalah menyelenggarakan pemungutan suara dengan biaya hemat dan penghitungan suara yang cepat dengan menggunakan sistem yang aman dan mudah untuk dilakukan audit. Dengan e-voting 
perhitungan suara akan lebih cepat, bisa menghemat biaya pencetakan surat suara, pemungutan suara lebih sederhana, dan peralatan dapat digunakan berulang kali.

2. Remote voting adalah suatu cara/metoda pemberian suara pemilih pada suatu tempat dimana saja, seperti di rumah, di kantor atau di jalan, artinya dilokasi mana saja asal ada kesempatan bisa melakukan pemilihan suara.

3. Supervised voting adalah suatu proses pemilihan suara (memberikan suara) yang diawasi oleh petugas/pejabat pemilihan umum (KPU).

4. Remote electronic voting adalah pemilihan suara pada suatu tempat dengan menggunakan perangkat elektronik, tanpa pengawasan petugas/pejabat pemilihan umum (KPU).

5. Internet Voting adalah pemilihan suara melalui media internet, bisa dimana saja seperti di rumah, diperjalanan atau di tempat yang sudah disediakan.

\subsection{Macam-Macam Teknologi Voting}

1. Kertas Suara/ Surat Pemilihan (Paper Ballots)

Tekonologi ini adalah teknologi yang pertama dalam peradaban umat manusia dalam berdemokrasi, dimana kertas suara dijadikan dasar untuk menghitung suara pemilih. Cara melakukan pemilihan adalah pemilih mengambil kertas suara yang sudah disediakan dalam bentuk formulir, nama-nama calon dan gambarnya sudah tercetak, setelah itu pemilih tinggal menusuk atau mencoblos photo atau simbol calon pilihannya dan memasukkannya ke dalam suatu kotak suara yang sudah disediakan oleh petugas. Selanjutnya team atau anggota panitia akan melakukan penghitungan suara.

\section{Lever Machines}

Teknologi berikutnya (Technological advance) adalah Lever Machines yang dimulai diperkenalkan pada tahun 1892 . Teknologi ini tidak terdapat dokumen suara. Pemilih memasukkan suara dalam suatu tempat dengan memilih daftar calon dan mengumpulkan masing-masing calon terpilih. Suara dicatat dan dihitung dengan Lever Machines.

\section{Punchcards}

Teknologi punchcard, pertama kali dipakai untuk menghitung suara dengan menggunakan komputer yang dimulai pada tahun 1964. Dalam sistem ini, suara dicatat dengan memilih lubang-lubang pada kartu atau kertas komputer dan selanjutnya komputer akan membaca kartu suara. Kartu suara adalah sebagai dokumen suara pemilih yang tercatat. Ada dua tipe dari sistem punchcard yaitu kotak nomor dicetak pada kartu suara, dimana setiap kotak untuk pemilihan suara. Dan yang lainnya disebut Datavote yang mempunyai lubang-lubang pemilih yang menyatakan nama-nama kandidat atau memilih kandidatnya dengan cara melubangi kertas punchcard yang dicetak pada kartu suara.

\section{Marksense Form}

Teknologi ini dinamakan optical scan yang dimulai digunakan pada tahun 1980 . Pada sistem ini pemilih menggunakan bentuk kertas dan menulis pada kotak atau bentuk oval berikut arah panah untuk mengarahkan calon pemilih. Jika suara sudah lengkap ditulis kemudian dibaca oleh komputer. Tulisan pemilih ditempatkan pada suatu tempat perhitungan dan selanjutnya akan dibaca melalui proses optical scanning dan langsung dihitung dengan bantuan mesin penghitung. Kira-kira 25 persen dari seluruh negara telah menggunakan alat dengan cara seperti ini. Pada tahun 1992 
telah meningkat dua kali lipat penggunaannya dan terus meningkat pemakainya.

\section{Electronic Voting}

Teknologi electronic voting dimulai pada tahun 1970 yang disebut teknologi pencatatan langsung secara elektronik atau lebih dikenal dengan istilah DRE (direct recording electronic). Cara memilih dengan sistem ini adalah dengan memilih kandidat yang sudah tercetak pada layar komputer. Pemilih hanya menekan tombol pada display atau pada alat atau piranti yang mirip. Contoh dari electronic voting adalah dengan menekan tombol suara pemilih langsung disimpan pada suatu piranti memori atau pada sirkuit memori non volatile. Jika peralatan pemilihan menggunakan keyboard tulisan suara akan dicatat secara elektronik. Salah satu bentuk electronic voting yang sedang dikembangkan adalah Internet Voting.

\section{Remote Voting}

Remote voting adalah suatu tempat pemungutan suara yang letaknya berjauhan atau pada tempat yang berbeda, teknologi ini bisa menggunakan kertas yang dikirim melalui surat suara atau kartu suara, atau menggunakan suatu perangkat dengan kata lain bagaimana dokumen suara bisa dikirim ke suatu tempat untuk dihitung ditempat yang lain, cara ini tidak ada bedanya dengan pemungutan suara melalui surat, jadi remote voting adalah pemungutan suara dari tempat yang berbeda hanya saja cara atau media yang berbeda atau perangkat yang digunakan bisa berbeda-beda.

\subsection{Badan Eksekutif Mahasiswa (BEM)}

Organisasi

mahasiswa

intrakampus adalah organisasi mahasiswa yang memiliki kedudukan resmi di lingkungan perguruan tinggi dan mendapat pendanaan kegiatan kemahasiswaan dari pengelola perguruan tinggi dan atau dari Kementerian/Lembaga. Tugas pokok BEM adalah mewakili mahasiswa, mengkoordinasikan kegiatan organisasi kemahasiswaan dalam bidang ekstrakurikuler di tingkat fakultas dan memberikan pendapat, usul dan saran kepada pimpinan fakultas terutama berkaitan dengan peran, fungsi dan pencapaian tujuan pendidikan nasional.

\subsection{PHP (Hypertext Preprocessor)} PHP adalah bahasa pemograman yang digunakan secara luas untuk penanganan pembuatan dan pengembangan sebuah situs web dan bisa digunakan bersamaan dengan HTML. PHP banyak dipakai untuk membuat situs web dinamis. Tujuan utama penggunaan bahasa ini adalah untuk memungkinkan perancang dan penulis halaman web menjadi dinamis dan cepat.

\subsection{MySQL}

MySQL merupakan salah satu sistem database yang menggunakan sql (structured query language) yakni bahasa yang berisi perintah-perintah untuk memanipulasi database, mulai dari melakukan perintah select untuk menampilkan isi database, insert atau menambahkan isi ke dalam database, delete atau menghapus isi database dan update atau mengedit database.

\section{METODE PERANCANGAN SISTEM}

Metode yang diterapkan dalam tahap perancangan $e$-voting BEM adalah dengan menggunakan model Waterfall: a. Analisa Sistem 
Pada tahap ini dilakukan analisa terhadap masukan, keluaran, proses, sumber data dan pengendalian atau control pada aplikasi $e$-voting.

b. Desain

$$
\text { Pada tahap ini dilakukan }
$$

penyusun sistem baru dan
menerangkannya secara tertulis, kegiatan yang dilakukan adalah perancangan sistem logis dimana perancangan ini terdiri dari 3 diagram, yaitu usecase diagram, activity diagram, sequence diagram.

c. Pengkodean

Pada proses pembuatan program adalah proses dimana hasil dari perancangan yang telah disesuikan dengan hasil pengamatan dijabarkan dalam bentuk program.

d. Pengujian

Pengujian fokus pada perangkat lunak secara dari segi logik dan fungsional dan memastikan bahwa semua bagian sudah diuji. Hal ini dilakukan untuk meminimalisir kesalahan (error) dan memastikan keluaran yang dihasilkan sesuai yang diinginkan.

\section{IV.PEMBAHASAN}

\subsection{Analisa Sistem}

Untuk memenuhi kebutuhan suatu sistem maka perlu didefinisikan kebutuhan sistem secara spesifik yang terdiri dari masukan, keluaran, proses dan sumber data.

\subsubsection{Analisa Masukan}

Kebutuhan masukan sistem $e$ voting ini berupa data pilihan dari pemilih yang akan diproses untuk menghasilkan pemenang dalam pemilihan BEM, sedangkan peralatan yang digunakan antara lain adalah mouse dan keyboard.

\subsubsection{Analisa Keluaran}

Kebutuhan informasi atau keluaran dari sistem e-voting antara lain sebagai berikut:

- Informasi calon

- Informasi TPS

- Informasi pemenang

- Informasi petugas

- Informasi pemilih

\subsubsection{Analisa Proses}

Proses-proses yang terjadi pada sistem $e$-voting antara lain sebagai berikut:

- Kelola pengumuman calon

- Kelola data petugas

- Kelola data pemilih

- Kelola data calon

- Kelola data TPS

- Kelola pemilihan

\subsubsection{Analisa Sumber Data}

Kebutuhan data dalam sistem $e$ voting antara lain adalah:

- Data calon

- Data TPS

- Data pemilih

- Data petugas

- Data fakultas

\subsection{Desain Sistem}

Pada tahap ini dilakukan penyusun sistem baru dan menerangkannya secara tertulis, kegiatan yang dilakukan adalah perancangan sistem logis dimana perancangan ini terdiri dari 3 diagram, yaitu usecase diagram, activity diagram, sequence diagram. 


\subsubsection{Business Use Case}
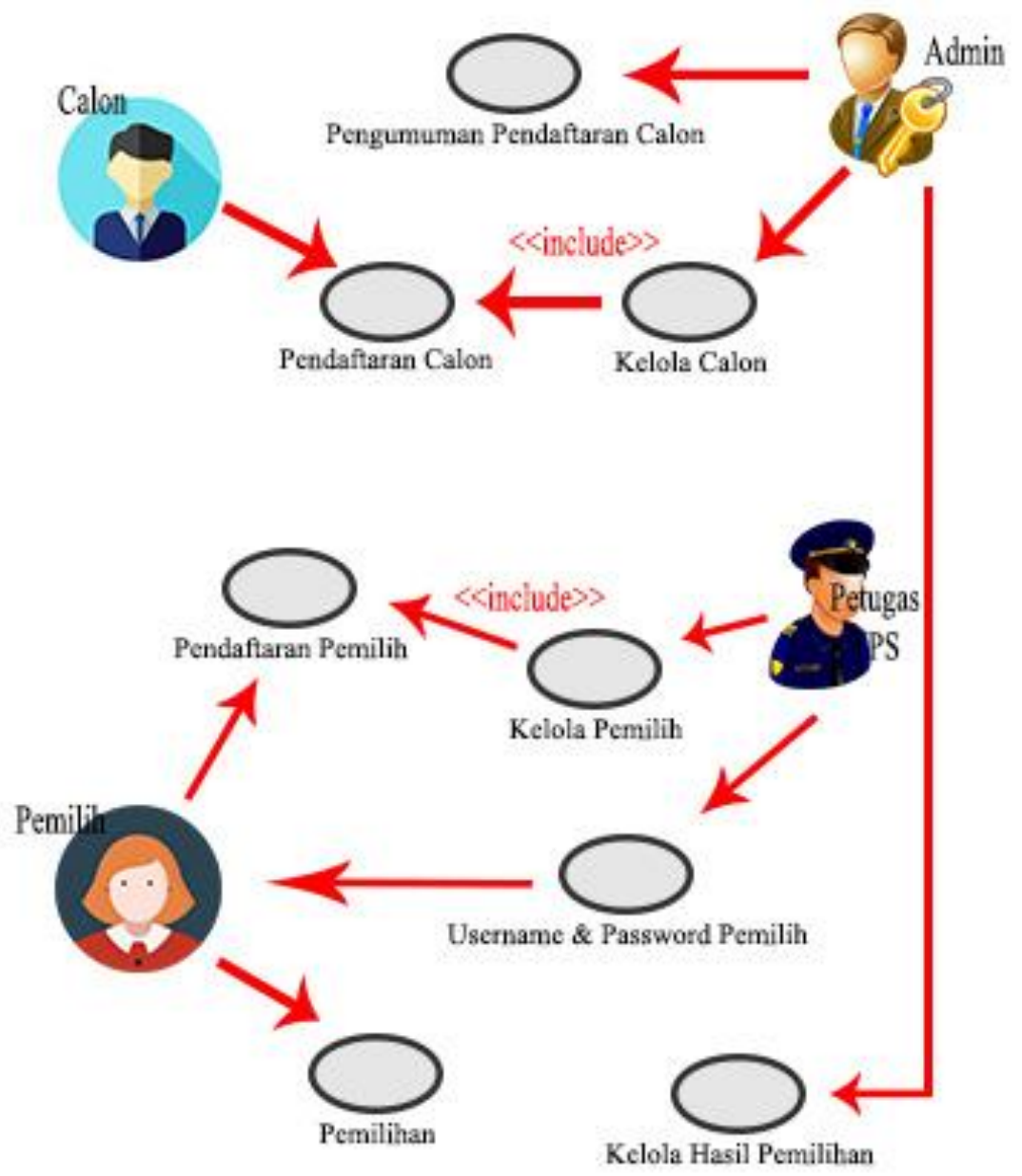

Gambar 1 Business Use Case E-Voting

Gambar 1 merupakan business use case diagram sistem $e$-voting terdapat dua bisnis aktor yaitu calon dan pemilih. Bisnis aktor calon berinteraksi dengan bisnis use case pendaftaran sedangkan bisnis aktor pemilih berinteraksi dengan pendaftaran pemilih, terima username dan password serta bisnis use case pemilihan. Bisnis worker terdiri dari admin dan petugas TPS, admin melakukan pengelolaan pengumuman pendaftaran, kelola calon serta kelola hasil pemilihan, sedangkan petugas TPS melakukan kelola pemilih yang dalam hal ini adalah mendaftarkan pemilih dan selanjutnya memberikan username dan password kepada pemilih. 


\subsubsection{Sistem Use Case}

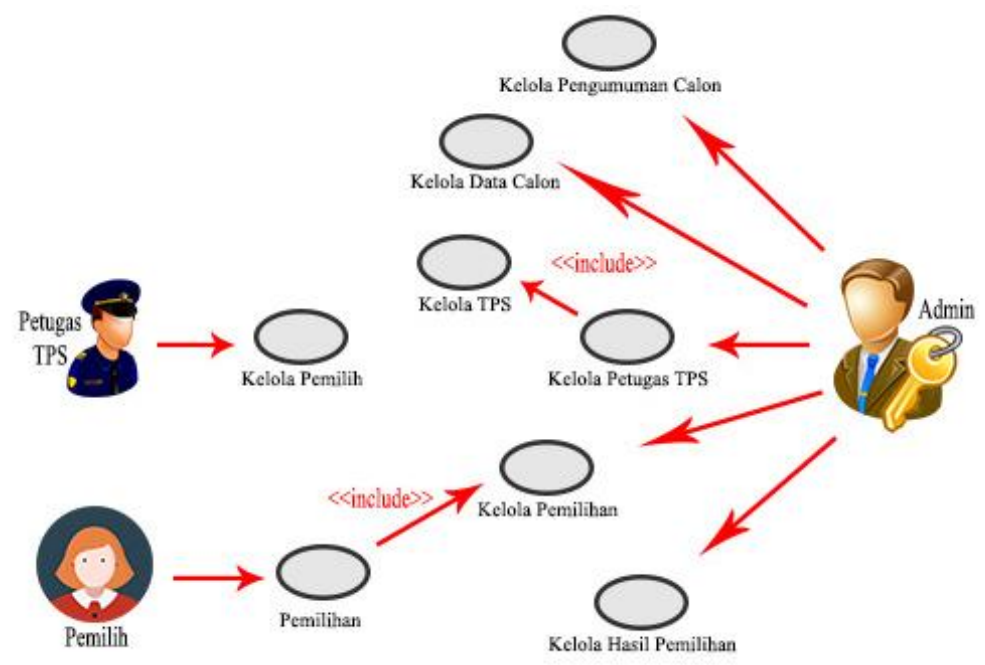

Gambar 2 Sistem Use Case

Gambar 2 merupakan use case sistem e-voting terdiri dari tiga aktor yaitu administrator yang berhak untuk melakukan kelola pengumuman pendaftaran calon, kelola data calon, kelola TPS dan petugasnya, kelola pemilihan serta kelola hasil pemilihan. Petugas TPS berinteraksi dengan sistem ketika melakukan pendaftaran pemilih adapun pemilih berinteraksi dengan sistem ketika melakukan pemilihan.

\subsubsection{Diagram Activity}

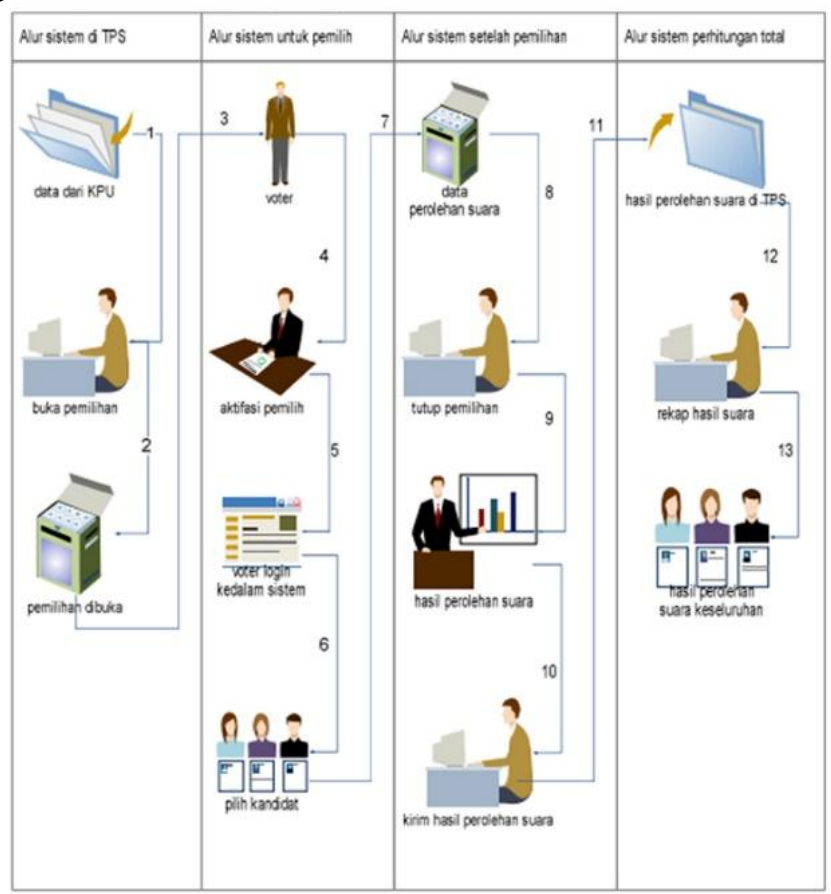

Gambar 3 Diagram Activity 
Gambar 3 merupakan diagram activity menunjukkan aktifitas petugas
TPS, pemilih dan sistem dalam proses pemilihan.

\subsubsection{Diagram Sequence}

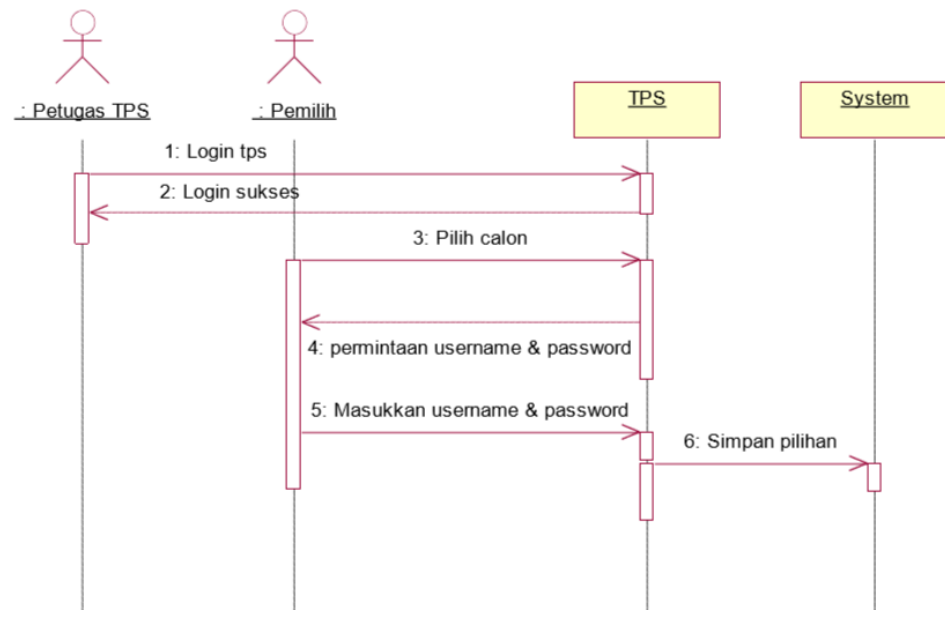

Gambar 4 Diagram Sequence

Gambar 4 merupakan diagram squence memperlihatkan proses penambahan data pemilihan yang dimulai dari proses login oleh petugas TPS.

\subsubsection{Flowchart}

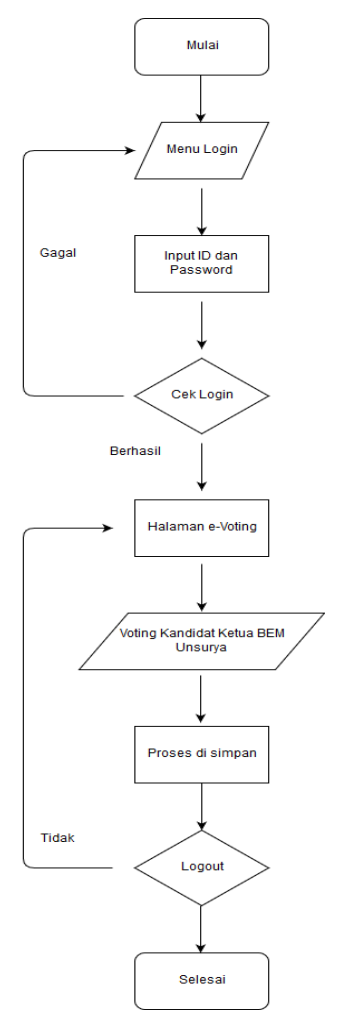

Gambar 5 Flowchart 
Gambar 5 merupakan bagan alir dalam sistem $e$-voting pemilihan BEM.

\subsubsection{Diagram Konteks}

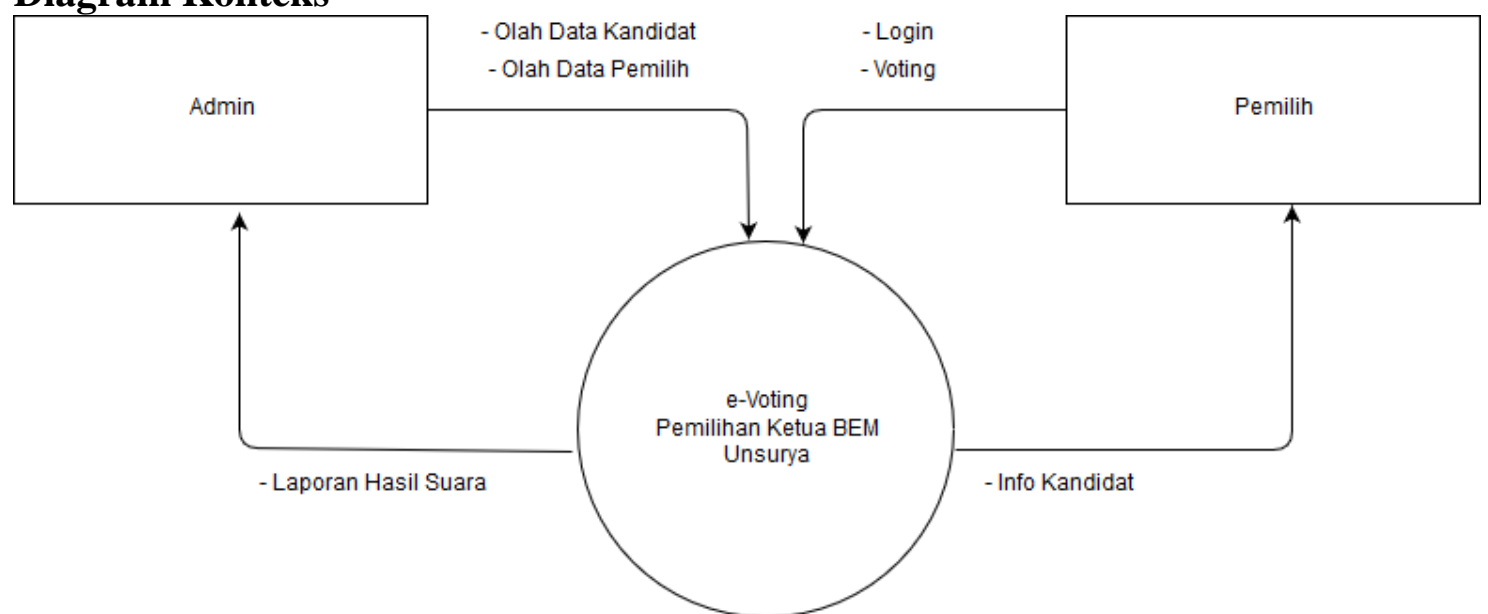

Gambar 6 Diagram Konteks

Gambar 6 merupakan diagram konteks yang menggambarkan sistem secara keseluruhan, semua eksternal entity yang terkait dengan sistem ini dan semua masukan serta keluaran yang mengalir diantaranya.

\subsubsection{Diagram Nol}

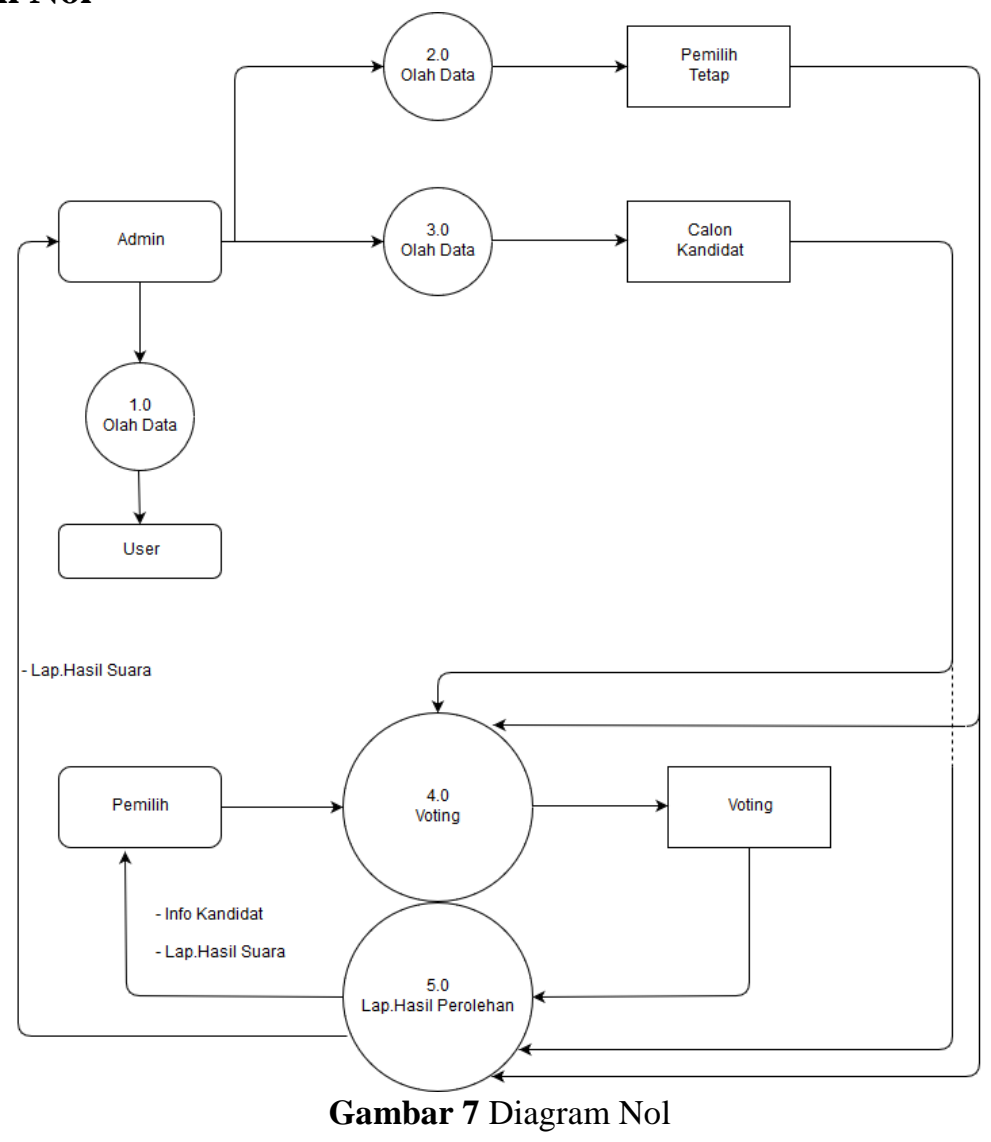


Gambar 7 merupakan Diagram Nol yang menggambarkan keseluruhan proses utama yang ada di dalam e-voting pemilihan BEM.

\subsubsection{Entity Relationship Diagram}

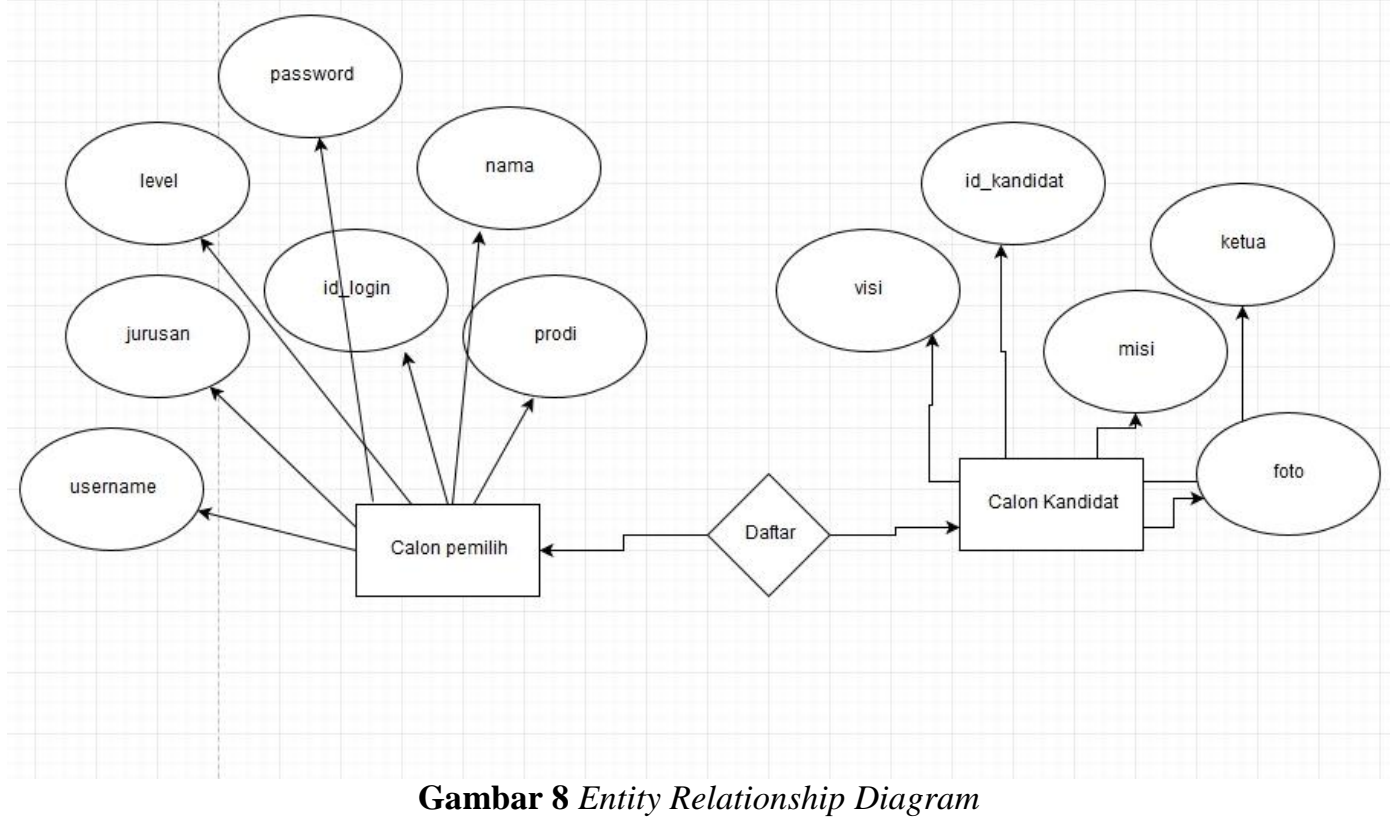

Gambar 8 merupakan diagram hubungan entitas dalam e-voting pemilihan BEM.

\subsubsection{Relasi Antar Tabel}

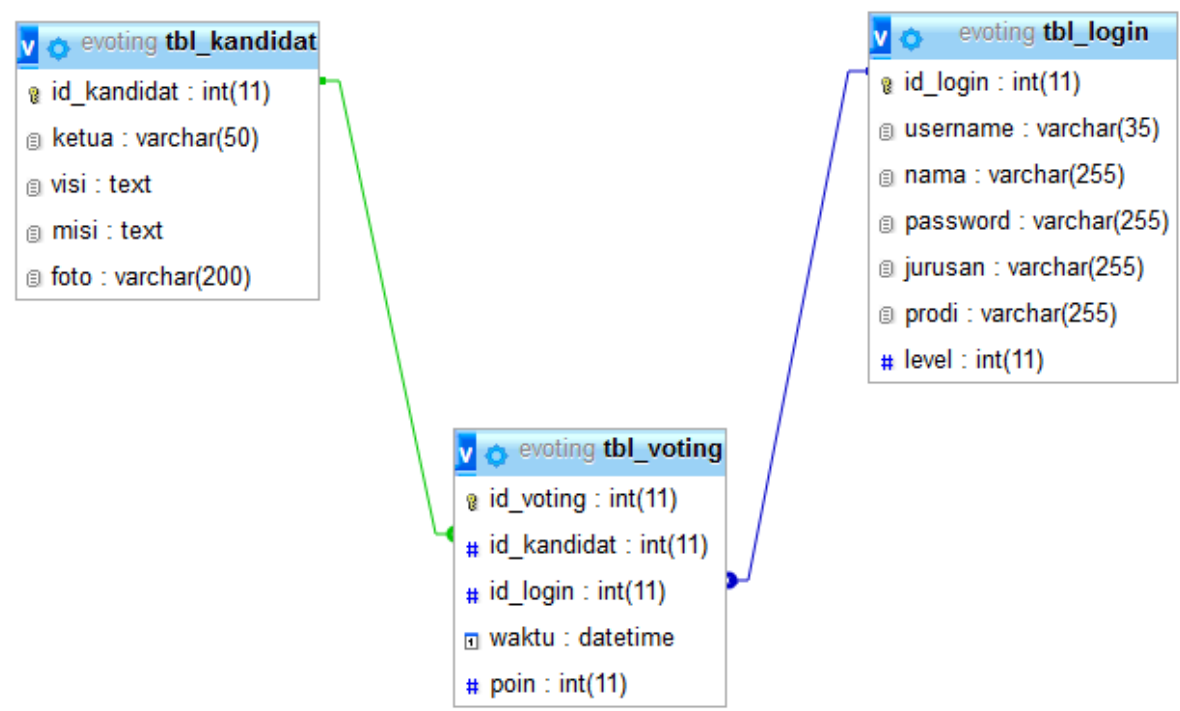

Gambar 9Relasi Antar Tabel

Gambar 9 merupakan relasi antar tabel dalam database $e$-voting pemilihan BEM. 
V. PENUTUP

\subsection{Kesimpulan}

a. Dengan adanya $e$-voting dapat mempercepat dan mempermudah proses pemilihan BEM Universitas Dirgantara Marsekal Suryadarma.

b. E-Voting akan mempermudah rekapitulasi perhitungan suara

c. E-Voting dapat meminimalisir jumlah golput dan kecurangan dalam pemilihan, yang selama ini sering terjadi.

d. Pemilihan dapat dilaksanakan secara efektif dan efisien.

\subsection{Saran}

a. Pengembangan tampilan yang lebih menarik lagi, tanpa mengurangi kemudahan dalam menggunakannya.

\section{DAFTAR PUSTAKA}

[1]

https://id.wikipedia.org/wiki/Pem ungutan_suara_elektronik

Diakses pada tanggal 15 Juli 2018 15:10 WIB

[2]

https://id.wikipedia.org/wiki/Bada n_eksekutif_mahasiswa

Diakses pada tanggal 15 Juli 2018 15:10 WIB

[3]

https://id.wikibooks.org/wiki/Pem rograman_PHP/Pendahuluan/Pen gertian_PHP

Diakses pada tanggal 15 Juli 2018 15:10 WIB

[4]

https://www.indosite.com/pengert ian-mysql

Diakses pada tanggal 15 Juli 2018 15:10 WIB

[5] Nugroho, A W. 2011. Perancangan E-Voting Berbasis WEB (Studi Kasus Pemilihan Kepala Daerah Sukoharjo). Skripsi, UIN Sunan Kalijaga Yogyakarta.

[6] Azhari, R. 2005. E-Voting, Jurnal Fakultas Ilmu Komputer, Universitas Indonesia, Jakarta. 